\title{
SYNCHRONISATION OF STOCK MARKET CYCLES: THE IMPORTANCE OF EMERGING AND DEVELOPED MARKETS TO ASEAN-5
}

\author{
Teng Kee Tuan, Yen Siew Hwa, Chua Soo Yean*
}

\begin{abstract}
:
This study analyses the directions and the degree of financial integration of ASEAN-5 with the PRC, India, the U.S. and Japan. A non-parametric approach has been used to study the crosscountry correlations based on Concordance Index $(\mathrm{Cl})$ and Rolling Concordance Index $(\mathrm{RCl})$. Monthly stock market indices between January 1991 and June 2010 for all the countries involved were analysed. The $\mathrm{Cl}$ results indicate higher financial interdependence of ASEAN-5 with the U.S. and Japan compared to the PRC and India. The stock markets RCls amongst ASEAN-5 with the emerging and developed economies depict a rising financial integration amongst these nations. Financial integration amongst ASEAN-5 stock markets with the PRC has gradually increased but is still relatively lower compared to the financial integration with India, the U.S. and Japan. Thus, the financial portfolio diversification of ASEAN-5 to the PRC is recommended, especially if the financial crisis originates from the ASEAN region.
\end{abstract}

Keywords: ASEAN-5, emerging economies, developed economies, financial integration, stock market indices, Concordance Index, Rolling Concordance Index.

JEL Classification: F15, F36

\section{Introduction}

The People's Republic of China (the PRC) and India are known for their sustainable impulsive economic growth and invulnerability to financial shocks, while ASEAN-5 economies have been experiencing moderate growth after their recovery from the 1997/98 Asian financial crisis. ${ }^{1}$ The U.S. economy has grown at a relatively slower

* Teng Kee Tuan, Tunku Abdul Rahman University College, Penang (tengkt@acd.tarc.edu.my), Yen Siew Hwa, School of Distance Education (Economics Section), Universiti Sains Malaysia (shyen@usm.my), Chua Soo Yean, School of Social Sciences, Universiti Sains Malaysia (sychua@usm.my).

1 In this study ASEAN-5 refers to the five founding members of the Association of Southeast Asian Nations, which are Indonesia, Malaysia, the Philippines, Singapore and Thailand. 
rate since 2000 compared to a few decades before and its economy has been further dragged down by the subprime mortgage and financial crisis. Japan has also experienced a disastrous decade of economic stagnation and deflation from 1991 to 2001 after its stock and property markets collapsed. However, its situation did not improve in recent years due to numerous natural disasters and nuclear crisis. These could pave the way for the uprising of the financial status in the PRC and India.

The PRC has just overtaken Japan as the world second largest economy in August 2010 and Shanghai Stock Exchange was ranked as the world top sixth stock exchange by domestic market capitalisation since 2011. ${ }^{2}$ In addition, Malaysia was approved as one of the Qualified Domestic Institutional Investor (QDII) destinations for Chinese investors in June 2010, while Singapore has already been in the QDII list since January 2008. ${ }^{3}$

Table 1 lists some of the quantitative characteristics of the stock markets for the emerging economies - the PRC and India; the developed economies - the U.S. and Japan; and ASEAN-5. This would provide us with some insight to each country's financial market development. The financial development is presented in four different perspectives, the number of listed domestic companies, market capitalisation of listed companies, stock traded over gross domestic product (GDP) ratio and stock turnover ratio. ${ }^{4}$

There are noticeable increases in the number of listed companies in the emerging stock markets, namely the PRC and India, over the time-span of the study as shown in Table 1, Panel A. The PRC's stock market was established with only 14 listed companies in 1991 and was able to expand to become the fourth highest in number of listed companies amongst these countries. India had the second highest number of listed companies after the U.S. and became the first after 2009 financial crisis in the U.S. The number of listed companies in ASEAN-5 is relatively small when compared to the four major economies. This makes ASEAN-5 financial markets more vulnerable to the influence from these major economies.

Since 1990, the PRC and India have shown a remarkable rise in market capitalisation ratio, stock traded ratio and stock turnover ratio until 2009. The rise could be attributed to the rapid financial market development and high economic growth experienced by these two economies over the last two decades. In 2010, all countries suffered a drop in the three indicators as a result of the global recession in 2009. These figures are shown in Table 1 panels B, C and D respectively. ${ }^{5}$

2 World Exchanges Organisation, http://www.world-exchanges.org/

3 QDII is a scheme for PRC's Investors, whom are allowed by the relevant Chinese authority to raise funds in Mainland China and to use the proceeds to invest offshore through a quota granted by the State Administration of Foreign Exchange (SAFE). Detailed reports on QDII list are available in http://www.chinaeconomicreview.com.

4 Source: http://data.worldbank.org/topic/financial-sector

5 Market capitalisation refers to a total market value of all outstanding shares for the listed company. The computation is the share price multiplied by the number of shares outstanding. Market capitalisation is positively related with GDP. Stock traded is the total value of shares traded during the period. Turnover ratio is computed by stock traded divided by market capitalisation. Low market liquidity infers low trading volume but high trading activities. 
Table 1

\section{Equity Markets in Selected Countries}

Panel A Listed domestic companies, total

\begin{tabular}{|l|cccccc|}
\hline Country & 1991 & 2000 & 2005 & 2007 & 2009 & 2010 \\
\hline PRC & 14 & 1,086 & 1,387 & 1,530 & 1,700 & 2,063 \\
India & 2,556 & 5,937 & 4,763 & 4,887 & 4,946 & 4,987 \\
United States & 6,742 & 7,524 & 5,143 & 5,130 & 4,401 & 4,279 \\
Japan & 2,107 & 2,561 & 3,279 & 3,844 & 4,161 & 3,553 \\
Indonesia & 141 & 290 & 335 & 383 & 401 & 420 \\
Malaysia & 321 & 795 & 1,020 & 1,036 & 953 & 957 \\
Philippines & 161 & 228 & 235 & 242 & 246 & 251 \\
Singapore & 166 & 418 & 685 & 472 & 459 & 461 \\
Thailand & 276 & 381 & 504 & 475 & 535 & 541 \\
\hline
\end{tabular}

Panel B Market capitalisation of listed companies (\% of GDP)

\begin{tabular}{|l|cccccc|}
\hline Country & 1991 & 2000 & 2005 & 2007 & 2009 & 2010 \\
\hline PRC & 0.53 & 48.48 & 34.92 & 184.09 & 100.44 & 80.40 \\
India & 17.83 & 32.18 & 68.27 & 154.57 & 85.62 & 93.60 \\
United States & 68.78 & 154.68 & 137.26 & 145.16 & 106.79 & 117.50 \\
Japan & 90.69 & 67.64 & 104.05 & 101.67 & 66.64 & 75.10 \\
Indonesia & 5.32 & 16.26 & 28.48 & 49.01 & 32.98 & 51.00 \\
Malaysia & 119.27 & 124.68 & 131.37 & 174.41 & 132.55 & 172.60 \\
Philippines & 25.10 & 34.19 & 40.63 & 71.66 & 49.71 & 78.80 \\
Singapore & 110.28 & 164.83 & 261.83 & 211.73 & 170.53 & 177.30 \\
Thailand & 36.44 & 24.03 & 70.80 & 79.34 & 52.39 & 87.20 \\
\hline
\end{tabular}

Panel C Stocks traded, total value (\% of GDP)

\begin{tabular}{|l|cccccc|}
\hline Country & 1991 & 2000 & 2005 & 2007 & 2009 & 2010 \\
\hline PRC & 0.22 & 60.20 & 26.22 & 230.37 & 179.65 & 135.50 \\
India & 8.65 & 110.78 & 53.56 & 94.11 & 79.06 & 61.20 \\
United States & 36.72 & 326.30 & 173.97 & 310.10 & 331.01 & 208.80 \\
Japan & 28.86 & 57.72 & 109.78 & 148.32 & 82.71 & 78.40 \\
Indonesia & 2.28 & 8.67 & 14.66 & 26.13 & 21.34 & 18.30 \\
Malaysia & 21.69 & 62.37 & 36.23 & 80.34 & 37.79 & 37.90 \\
Philippines & 3.27 & 10.80 & 7.03 & 20.31 & 10.67 & 13.40 \\
Singapore & 41.87 & 98.67 & 99.07 & 230.15 & 138.43 & 135.10 \\
Thailand & 30.63 & 18.95 & 50.63 & 43.79 & 51.16 & 68.40 \\
\hline
\end{tabular}

Panel D Stocks traded, turnover ratio (\%)

\begin{tabular}{|l|cccccc|}
\hline Country & 1991 & 2000 & 2005 & 2007 & 2009 & 2010 \\
\hline PRC & - & 158.29 & 82.55 & 180.10 & 229.52 & 164.37 \\
India & 56.78 & 133.64 & 94.20 & 84.00 & 116.32 & 75.62 \\
United States & - & 200.80 & 129.10 & 216.50 & 348.58 & 189.06 \\
Japan & - & 69.90 & 118.78 & 141.60 & 127.08 & 114.49 \\
Indonesia & 40.12 & 32.92 & 54.18 & 64.40 & 78.06 & 48.11 \\
Malaysia & 20.16 & 44.59 & 26.87 & 53.50 & 54.66 & 27.07 \\
Philippines & 18.85 & 15.84 & 20.12 & 34.10 & 24.89 & 22.55 \\
Singapore & - & 52.10 & 63.09 & 122.00 & 102.80 & 82.88 \\
Thailand & 102.16 & 53.20 & 74.74 & 64.20 & 110.23 & 104.80 \\
\hline
\end{tabular}

Source: http://data.worldbank.org/topic/financial-sector 
The PRC and India gradual development in their financial markets maturity status have become virtually parallel with the renowned matured stock markets like the U.S. and Japan. ${ }^{6}$ This remark is supported by the PRC and India growth in number of listed companies, high turnover ratio and high stocks traded over GDP. In view of this changes, will the PRC and India financial markets transformation pose any threat to ASEAN-5 stock markets, which is relatively concentrated and immature? Will ASEAN-5 gain by diversifying equity portfolio in the PRC and India?

This study investigates the extent of ASEAN-5 stock market integration towards the changes in the emerging and developed economies. Specifically it analyses the possible changes in the direction and degree of financial integration of ASEAN-5 with the four economies - the PRC, India, the U.S. and Japan. It follows a non-parametric approach to explore the possibility of stock portfolio diversification in short-term and long-term horizons amongst these markets. This approach will be used to study the cross-country correlations based on concordance index (CI) and Rolling Concordance Index (RCI).

\section{Review of Literature}

The empirical findings on the extent of financial integration in Asia region are mixed as the level of financial integration changes over time. ASEAN-5 stock markets are becoming more integrated especially during the post-1997 Asian financial crisis (Click and Plummer, 2005; Lim, 2009; Majid, et al., 2009). Phylaktis and Ravazzolo (2002), Rana (2007) and Majid, et al. (2009) found that the financial integration in East Asia region is rising since 1989, which is before 1997 Asian financial crisis. ${ }^{7}$ While Majid, et al. (2009), Guillaumin (2009), Lim (2009), as well as Lean and Ghosh (2010) concluded that the financial integration in East Asia region only increased after the 1997 Asian financial crisis. Yu, et al. (2010) suggested that Asia financial integration only started to rise at the end of 2007. It is interesting to note that the results obtained for the kick-off point of financial integration in Asia region are varied by a decade. In fact, difference in the pick-up point of financial integration depends greatly on the combination of countries for Asia region and the methodologies used in the study.

Most of the previous empirical studies focused on the PRC stock market integration with the U.S., Japan and South Korea. However, there is still lack of studies on the stock market linkages between ASEAN-5 and the PRC. Girardin and Liu (2007) discovered that the PRC and the U.S. are not integrated in their stock market over the period of 1992-2005. Azad (2009) indicated that PRC stock market is financially integrated with Japan and South Korea. In contrast, Huang, et al. (2000) concluded that absence of financial integration between Chinese stock market and Japanese stock market is because PRC stock market is still isolated from the rest of the world.

6 The PRC was still in the category of emerging market under the study conducted by IMF (Beirne, et al., 2009) for the study period September 1993 until March 2008.

7 East Asian region in Rana (2007) consists of the PRC, Hong Kong, PRC, Indonesia, Korea, Singapore, Thailand and Taiwan while Phylaktis and Ravazzolo (2002) sample countries are Hong Kong, Taiwan, Indonesia, Korea, Malaysia, the Philippines, Singapore and Thailand. 
Studies carried out in the late 2000s begun to observe that Chinese stock market has become more integrated with East Asian countries (Karim and Majid, 2009; Azad, 2009; Lean and Ghosh, 2010). However, Huyghebaert and Wang (2010) and Yu, et al. (2010) indicated that the PRC stock market is still detached from other countries and only weakly integrated with the Asian region. This situation implies that there is room for the study of financial integration between the PRC and ASEAN-5 with the rise of PRC as ASEAN's second major trading partner in 2009.

Financial interdependency could be measured based on the stock market synchronisation through the CONCORDANCE INDex (CI) and Rolling Concordance Index (RCI) proposed by Harding and Pagan $(2002,2005)$. A few studies that adopted these methods in assessing cross-country financial markets correlation are Edwards, et al. (2003) and Yu et al. (2010). CI and RCI measured the degree of concordance of a country's cycle with reference cycle. CI and RCI indicated whether the two variables movement are at the same phase of the cycle or not. These indices can be used to compare the cycle concordance of two or more countries during the bull or bear phases in the stock market. The shortcoming of RCI is the problem of overlapping data and they are not constant over time (Bekaert and Harvey, 1997; Baele, et al., 2004). Hence, this method can be used as a complementary method to support the results generated by a parametric approach. Meric, et al. (2001) used the rolling of unconditional correlation to study the stock market correlation amongst the U.S. with Argentina, Brazil, Chile and Mexico.

\section{Methods and Data}

The dynamic interdependency amongst stock returns for the nine stock markets can be analysed by looking at the Concordance Index (CI) and Rolling Concordance Index (RCI). These indices are generated by a non-parametric method to measure the degree of integration amongst different markets. ${ }^{8}$ Cycle synchronisation can be used to indicate financial interdependencies among countries. A high (low) degree of cyclical synchronisation between two countries implies rising (falling) co-movement of cycles between the economies and signals increasing (decreasing) integration between the economies. Consequently, it becomes less (more) profitable to diversify asset portfolio between these two economies.

CI measures the degree of synchronisation between the cycles of two countries, while RCI exhibits the trend in degree of synchronisation between the cycles of two countries. In other word, CI shows the average frequency of two economies' market regimes coincide over time, while RCI illustrates the average frequency with fixed rolling window width of two economies' market phases coincide over time, which is more dynamic compared to CI. CI and RCI range from zero to one. CI moving towards unity (zero) indicates increasing (reducing) market synchronisation and rising (reducing) degree of integration. While the upward (downward) trend of RCI shows the rising (falling) of both cycles concordance (divergence) and denotes growing (declining) financial integration.

8 Follows the method used by Harding and Pagan (2002, 2005), Pagan and Sossounov (2003). 
This study explores the dynamic linkages amongst financial market cycles and investigates the nature link between financial market cycles. It allows us to observe whether the two markets are more or less coincided during bullish (cyclical upswing) or bearish (cyclical downswing) periods. If both cycles coincide more during the bear market (cyclical downswing), it implies that the cycles are synchronised during market downturn. Hence, the contagion effect exists between these markets. Diversification of portfolio between these two markets is not beneficial to both countries (Arouri, et al., 2008; Arouri and Nguyen, 2009). This is because, to a certain extent, synchronisation in financial cycles indicates the integration of both markets (Yu, et al., 2010).

In order to specify the cyclical phases, the turning points (the peaks and troughs) are determined by Bry and Boschan (B\&B) procedure (Pagan and Sossounov, 2003; Edwards, et al., 2003). The turning points obtained by B\&B procedure have been adopted to identify the acceleration stage and deceleration stage in the stock market cycle since $1971 .^{9}$

\section{Bry and Boschan (B\&B) Procedure}

Locating peaks and troughs are the most important elements in B\&B procedure as they make distinction between expansions and contractions, which form a cyclical turns in stock market cycle. According to B\&B procedure, a peak and a trough of a return series $\left(r_{\mathrm{t}}\right)$ is identified if $r_{\mathrm{t}}$ is the highest or lowest in a window of width 8 months. ${ }^{10}$

Peak is located at $\mathrm{t}$ if $\left[r_{\mathrm{t}-8, \ldots,}, r_{\mathrm{t}-1}<r_{\mathrm{t}}>r_{\mathrm{t}+1,}, \ldots, r_{\mathrm{t}+8}\right]$

Trough is located at $\mathrm{t}$ if $\left[r_{\mathrm{t}-8, \ldots .,}, r_{\mathrm{t}-1}>r_{\mathrm{t}}<r_{\mathrm{t}+1,}, \ldots, r_{\mathrm{t}+8}\right]$

The detailed explanations for the set of restrictions for locating peaks and troughs for stock market cycle are shown in Appendix I. ${ }^{11}$

\section{Duration of the Cyclical Movements}

Phases of stock market cycle are determined after locating the peaks and troughs of stock market cycle. There are two phases in each cycle, which are expansion and contraction. Expansion phase is from the trough to peak, while contraction phase is from the peak to trough. The duration in months spent on each of the phases in stock market cycle is calculated. The average duration (AD) in months spent on expansion and contraction of a stock market cycle is computed after the generation of duration for each phase of stock market cycle.

9 B\&B procedure was originally developed to locate the turning points for growth rate cycle's peaks and troughs and latter was modified to locate the peaks and troughs for stock market cycle by Pagan and Sossounov (2003).

10 This research follows Pagan and Sossounov (2003) using eight months as window width for a total width of the window of 16 months.

11 Statistical package GAUSS 9.0 is used for the estimation procedure of stock market cycle. 
The first step to compute duration and $\mathrm{AD}$ of each phase is to define the phases. The expansion and contraction are defined by using binary random variables. The expansion at the time $t$, indicates by $\mathrm{S}_{\mathrm{t}}$ equals to one while contraction at the time $t$ is $\mathrm{S}_{\mathrm{t}}-1$, which equals to zero.

Next, the total time spent in an expansion is $\sum_{t=1}^{T} S_{t}$ and the number of peaks (expansion), which denoted as NTP (number of trough to peak), is $\sum_{t=1}^{T}\left(1-S_{t+1}\right) S_{t}-1$. Hence, AD for expansion is $N T P^{-1} \sum_{t=1}^{T} S_{t}$.

\section{Concordance Index (CI), and Rolling Concordance Index (RCI)}

According to Harding and Pagan (2002), to measure the degree of synchronisation between the cycles of two countries, CI is generated by using the formula below: ${ }^{12}$

$$
C I_{i j}=\frac{1}{T} \sum_{t=1}^{T}\left[s_{i, t} s_{j, t}+\left(1-s_{i, t}\right)\left(1-s_{j, t}\right)\right]
$$

where $S_{i, t}$ and $S_{j, t}$ are the expansion of country $i$ and $j$ respectively at time $t$, with the value of one. $\left(1-S_{i, t}\right)$ is the contraction of country $i$ at time $t$ with the value zero. The CI computed is between the value of zero and one. If the CI equals one, the two countries' cycle movement is said to be perfectly synchronised and vice versa. The higher the CI, the bilateral cyclical movement of the two countries is more synchronised. If the CI is 0.5 or slightly above 0.5 , there is no strong evidence that, both countries' cycles are synchronised. Under this condition, both cycles can be interpreted as either $50 \%$ concordance with each other or $50 \%$ not concordance with each other (Edwards et al., 2003; Avouyi-Dovi and Matheron, 2005).

The computation of CI to reveal stock market cycle synchronisation is using the stock return between ASEAN-5 with emerging economies and developed economies, respectively.

After computing the CI and the relationship of two countries' cycles will be revealed, the following step is to determine the trend of the degree of concordance for the two countries. RCI indicates whether the trend of cycles for the two countries is moving upward or downward together. According to Harding and Pagan (2002), the RCI can be expressed as follows:

$$
\operatorname{RCI}_{i j}^{\varphi}=\frac{1}{50} \sum_{t=\varphi-49}^{\varphi}\left[s_{i t} \cdot s_{j t}+\left(1-s_{i t}\right)\left(1-s_{j t}\right)\right]
$$

The upward (downward) trend of RCI shows the rising (falling) of both cycles concordance. The trend of concordance for two markets can be shown by using a plotted diagram.

$12 \mathrm{CI}$ and RCI are generated by using Microsoft Excel. 


\section{Data Description}

Monthly data for the stock market indices were obtained from the IMF, International Financial Statistics. This study covers the period of January 1991 to June 2010. The market indices for the emerging and developed economies are Shanghai Stock Exchange Composite Index (SHCI), Bombay Stock Exchange (BSE), Dow Jones Industrial Index (DJII) and Nikkei 225 Stock Average Price Index (NIK). The stock markets indices for the ASEAN-5 are Jakarta Stock Exchange Composite Stock Price Index (JSE), Kuala Lumpur Stock Exchange Composite Price index (KLCI), the Philippines Stock Exchange Composite Price index (PSE), Straits Times Stock Exchange Index of Singapore (SSI) and Bangkok Stock Exchange Price Index (THSE).

\section{Analysis of Results}

This section presents the cyclical analysis of stock market for all the selected countries in this study. The cyclical analysis is reviewed from the number of peaks and troughs, expansion and contraction regimes, average duration spent at each regime, Concordance Index and Rolling Concordance Index.

\section{Phases of Stock Market Cycle}

The dates of the estimated peaks and troughs for each country's stock market are shown in Tables $2 \mathrm{a}, 2 \mathrm{~b}, 2 \mathrm{c}, 2 \mathrm{~d}$ and $2 \mathrm{e}$. The corresponded expansion and contraction regimes with its duration for stock market cycles are also indicated in those tables.

Tables $2 \mathrm{a}$ and $2 \mathrm{~b}$ represent the cycles in the PRC and India respectively. Tables $2 \mathrm{c}$ and $2 \mathrm{~d}$ show the cycles in the U.S. and Japan. There were seven peaks and seven troughs in the PRC stock market (SHCI) cycles during the sample period given in Table 2a. The average duration of downturn was about 18 months and of upturn is 14 months. During the period, there were seven complete upturns and seven complete downturns in the PRC stock market. There was a major slide in the PRC stock market, between July 1999 and May 2005. This bear phase lasted for 71 months, which was the longest in the history of the PRC stock market since their establishment in December 1990. The slowdown of the PRC stock market was resulted from the restructuring of the PRC's financial system and the progressively liberalisation of its stock market such as, the "Guquanfenzhi" reform (stock ownership group) in 2001. The chaos caused by the "Guquanfenzhi" reform has led to the government temporarily abandoning the plan in the same year. The stock market slump ended when the government resumed the plan in April 2005 and decided on the conversion of state-owned shares to tradable shares ("Guquanfenzhi" reform). Since then, PRC stock market started its 27 months of bull market (June 2005-August 2007). 
Table 2a

Stock Market Cycles in PRC

\begin{tabular}{|l|c|c|c|c|c|c|c|}
\hline & SHCl & Bear & Period & $\begin{array}{c}\text { Duration } \\
\text { (months) }\end{array}$ & Bull & Period & $\begin{array}{c}\text { Duration } \\
\text { (months) }\end{array}$ \\
\hline Peak at & May-92 & Jun-92 & Oct-92 & 5 & & & \\
\hline Trough at & Oct-92 & & & & Nov-92 & Aug-94 & 22 \\
\hline Peak at & Aug-94 & Sep-94 & Apr-95 & 8 & & & \\
\hline Trough at & Apr-95 & & & & May-95 & Jun-96 & 14 \\
\hline Peak at & Jun-96 & Jul-96 & Dec-96 & 6 & & & \\
\hline Trough at & Dec-96 & & & & Jan-97 & Dec-97 & 12 \\
\hline Peak at & Dec-97 & Jan-98 & Aug-98 & 8 & & & \\
\hline Trough at & Aug-98 & & & & Sep-98 & Jun-99 & 10 \\
\hline Peak at & Jun-99 & Jul-99 & May-05 & 71 & & & \\
\hline Trough at & May-05 & & & & Jun-05 & Aug-07 & 27 \\
\hline Peak at & Aug-07 & Sep-07 & Mar-08 & 7 & & & \\
\hline Trough at & Mar-08 & & & & Apr-08 & Jun-09 & 15 \\
\hline Peak at & Jun-09 & Jul-09 & Aug-09 & 2 & & & \\
\hline Trough at & Aug-09 & & & & Sep-09 & & \\
\hline Average Duration & & & 18 & & & 14 \\
\hline
\end{tabular}

Source: Author's calculations

In the case of India stock market (BSE) as shown in Table 2b, during the same sample period, there were eight peaks and seven troughs. The average duration of bear period was 12 months and of bull period was 16 months. There were eight complete bear cycles and seven complete bull cycles. Over the period of study, there were two bear periods, which dragged around 24.5 months (December 1993-November 1995 and May 1996-May 1998). The former downturn period coincided with the phases of financial liberalisation, which took place in India. While the latter downturn period is related to the implementation of a series of tight monetary measures in respond to the Asian financial crisis although India was not affected by the crisis. The successful financial liberalisation in India stock market has led to subsequent sustainable bull periods with a few short bear periods. 
Table 2b

Stock Market Cycles in India

\begin{tabular}{|l|c|c|c|c|c|c|c|}
\hline & BSE & Bear & Period & $\begin{array}{c}\text { Duration } \\
\text { (months) }\end{array}$ & Bull & Period & $\begin{array}{c}\text { Duration } \\
\text { (months) }\end{array}$ \\
\hline Peak at & Mar-92 & Apr-92 & May-92 & 2 & & & \\
\hline Trough at & May-92 & & & & Jun-92 & Nov-93 & 18 \\
\hline Peak at & Nov-93 & Dec-93 & Nov-95 & 24 & & & \\
\hline Trough at & Nov-95 & & & & Dec-95 & Apr-96 & 5 \\
\hline Peak at & Apr-96 & May-96 & May-98 & 25 & & & \\
\hline Trough at & May-98 & & & & Jun-98 & Dec-99 & 19 \\
\hline Peak at & Dec-99 & Jan-00 & Mar-00 & 3 & & & \\
\hline Trough at & Mar-00 & & & & Apr-00 & Apr-01 & 13 \\
\hline Peak at & Apr-01 & May-01 & Jul-02 & 15 & & & \\
\hline Trough at & Jul-02 & & & & Aug-02 & May-05 & 34 \\
\hline Peak at & May-05 & Jun-05 & May-06 & 12 & & & \\
\hline Trough at & May-06 & & & & Jun-06 & Oct-07 & 17 \\
\hline Peak at & Oct-07 & Nov-07 & Nov-08 & 13 & & & \\
\hline Trough at & Nov-08 & & & & Dec-08 & May-09 & 6 \\
\hline Peak at & May-09 & Jun-09 & & & & & \\
\hline Average Duration & & & 12 & & & 16 \\
\hline
\end{tabular}

Source: Author's calculations

The major world reference stock market cycle, the U.S. DJII reflected a more stable and less frequent regimes switching during the period of study. As indicated in Table 2c, there were only five troughs and peaks, which occurred at the same time with five complete bull and bear markets observed for the sample period. The average period spent in bull market ( 27 months) is 1.5 times longer than bear period (18 months). The U.S. stock market enjoyed long bull period of 68 months from December 1991 until July 1997. The regime switched to bear phase which coincided with the Asian financial crisis. The subsequent change in patterns indicates relatively shorter bull periods while the bear periods became relatively longer. There was an exception in January 2003 with the bull phase lasted for 46 months long. The stock market in the U.S. picked up its momentum after resuming from the 2002 stock market downturn. The following bear period generated in this study, November 2006-October 2008 was almost similar to the official bear phase announced by the U.S. authority, October 2007-June 2009. The difference could be due to the method used in generating the turning points. There are a few arguments on the root cause of the bear market, such as the economic slowdown in the U.S and the political administration in the U.S. 
Table 2c

Stock Market Cycles in U.S.

\begin{tabular}{|l|c|c|c|c|c|c|c|}
\hline & DJII & Bear & Period & $\begin{array}{c}\text { Duration } \\
\text { (months) }\end{array}$ & Bull & Period & $\begin{array}{c}\text { Duration } \\
\text { (months) }\end{array}$ \\
\hline Trough at & Nov-91 & & & & Dec-91 & Jul-97 & 68 \\
\hline Peak at & Jul-97 & Aug-97 & Aug-98 & 13 & & & \\
\hline Trough at & Aug-98 & & & & Sep-98 & Apr-99 & 8 \\
\hline Peak at & Apr-99 & May-99 & Mar-01 & 23 & & & \\
\hline Trough at & Mar-01 & & & & Apr-01 & Nov-01 & 8 \\
\hline Peak at & Nov-01 & Dec-01 & Dec-02 & 13 & & & \\
\hline Trough at & Dec-02 & & & & Jan-03 & Oct-06 & 46 \\
\hline Peak at & Oct-06 & Nov-06 & Oct-08 & 24 & & & \\
\hline Trough at & Oct-08 & & & & Nov-08 & Mar-09 & 5 \\
\hline Peak at & Mar-09 & Apr-09 & & & & & \\
\hline Average Duration & & & 18 & & & 27 \\
\hline
\end{tabular}

Source: Author's calculations

Table $2 \mathrm{~d}$ shows that the estimated number of peaks and troughs in the Japanese stock market (NIK) were six and seven, respectively. The mean duration observed for stock market contraction was 28 months while expansion was 10 months. Japan seemed to spend double of the time in their contraction compared to its expansion period. There were six complete cycles of bear market and five for bull market. Japan stock market dipped into a long bear period from April 1993 until March 1998. In fact, Japan was in their 'Lost Decades' during the bear period. ${ }^{13}$ The turning point to bull market in April 1998 was supported by the implementation of financial market reform. The upturns and downturns phases of Japan stock market seemed to be not closely associated with timeline of the major financial crises eruption in the other selected countries of this study. However, the Japanese stock markets continued dipping in bear market since December 2005 until today with a short revival of five months in November 2008.

13 The period from 1991 until 2000 is defined as the Lost Decade of Japan economy. Japanese economy entered into the Lost Decade after the gradual collapse of the Japanese asset price bubble. Recently, the Lost Decade expanded to 2010 hence with the time span of 20 years. The term changed to the Lost Decades. 
Table 2d

Stock Market Cycles in Japan

\begin{tabular}{|l|c|c|c|c|c|c|c|}
\hline & NIK & Bear & Period & $\begin{array}{c}\text { Duration } \\
\text { (months) }\end{array}$ & Bull & Period & $\begin{array}{c}\text { Duration } \\
\text { (months) }\end{array}$ \\
\hline Peak at & Mar-93 & Apr-93 & Mar-98 & 60 & & & \\
\hline Trough at & Mar-98 & & & & Apr-98 & Mar-99 & 12 \\
\hline Peak at & Mar-99 & Apr-99 & Apr-00 & 13 & & & \\
\hline Trough at & Apr-00 & & & & May-00 & Apr-01 & 12 \\
\hline Peak at & Apr-01 & May-01 & Aug-01 & 4 & & & \\
\hline Trough at & Aug-01 & & & & Sep-01 & May-03 & 21 \\
\hline Peak at & May-03 & Jun-03 & Apr-05 & 23 & & & \\
\hline Trough at & Apr-05 & & & & May-05 & Nov-05 & 7 \\
\hline Peak at & Nov-05 & Dec-05 & Oct-08 & 35 & & & \\
\hline Trough at & Oct-08 & & & & Nov-08 & Mar-09 & 5 \\
\hline Peak at & Mar-09 & Apr-09 & & & & & \\
\hline Average Duration & & & 28 & & & 10 \\
\hline
\end{tabular}

Source: Author's calculations

Table 2e reports the turning points for all the ASEAN-5 stock markets. Indonesian stock market (JSE) observed eight peaks and seven troughs with the average duration of 17 months for bear phases and 12 months for bull phases. Hence, there were eight full bear cycles and seven full bull cycles. As for Malaysian stock market (KLCI), there were four peaks and five troughs over the span of study. The bear and bull duration were 37 months and 12 months, respectively. Therefore, four full bear cycles and five bull cycles were recorded. The stock market cycles' turning points estimated in the Philippines are 14 (7 peaks and 7 troughs), 12 for Singapore, SSI (6 peaks and 6 troughs) and 12 for Thailand, THSE ( 6 peaks and 6 troughs). The mean duration for stock market downturns is 15 months for the Philippines (PSE), 25 months for Singapore and 11 months for Thailand. The mean duration for stock market upturns is 17 months for the Philippines, 13 months for Singapore and 22 months for Thailand. Seven complete stock market cycles for both bull and bear are observed in the Philippines, six in Singapore and Thailand.

It is interesting to note that the troughs that coincide in time amongst ASEAN-5 stock markets were August 1997 and October 2008. These trough dates come simultaneously with the outbreak of Asian financial crisis for the former date while financial crisis in the U.S. and EU for the latter date (Singapore's trough was one month earlier). Most ASEAN-5 stock markets are characterized with frequent changes in regimes except Malaysian stock market. According to the data, ASEAN-5 stock markets were in the bear phases during the 1994 U.S. bond crisis, collapse of IT bubble (2000-2002) and subprime financial crisis (2007-2008). 
Table 2e

Stock Market Cycles in ASEAN-5

\begin{tabular}{|l|c|c|c|c|c|c|c|}
\hline & JSE & Bear & Period & $\begin{array}{c}\text { Duration } \\
\text { (months) }\end{array}$ & Bull & Period & $\begin{array}{c}\text { Duration } \\
\text { (months) }\end{array}$ \\
\hline Peak at & Jan-92 & Feb-92 & Nov-92 & 10 & & & \\
\hline Trough at & Nov-92 & & & & Dec-92 & Aug-93 & 9 \\
\hline Peak at & Aug-93 & Sep-93 & Jan-95 & 17 & & & \\
\hline Trough at & Jan-95 & & & & Feb-95 & Jan-96 & 12 \\
\hline Peak at & Jan-96 & Feb-96 & Aug-97 & 19 & & & \\
\hline Trough at & Aug-97 & & & & Sep-97 & Nov-98 & 15 \\
\hline Peak at & Nov-98 & Dec-98 & May-00 & 18 & & & \\
\hline Trough at & May-00 & & & & Jun-00 & Jan-02 & 20 \\
\hline Peak at & Jan-02 & Feb-02 & Jan-03 & 12 & & & \\
\hline Trough at & Jan-03 & & & & Feb-03 & Sep-03 & 8 \\
\hline Peak at & Sep-03 & Oct-03 & Apr-05 & 19 & & & \\
\hline Trough at & Apr-05 & & & & May-05 & Aug-06 & 16 \\
\hline Peak at & Aug-06 & Sep-06 & Oct-08 & 26 & & & \\
\hline Trough at & Oct-08 & & & & Nov-08 & May-09 & 7 \\
\hline Peak at & May-09 & Jun-09 & & & & & \\
\hline Average Duration & & & 17 & & & 12 \\
\hline
\end{tabular}

\begin{tabular}{|l|c|c|c|c|c|c|c|}
\hline & KLCl & Bear & Period & $\begin{array}{c}\text { Duration } \\
\text { (months) }\end{array}$ & Bull & Period & $\begin{array}{c}\text { Duration } \\
\text { (months) }\end{array}$ \\
\hline Trough at & Aug-92 & & & & Sep-92 & Dec-93 & 16 \\
\hline Peak at & Dec-93 & Jan-94 & Mar-94 & 3 & & & \\
\hline Trough at & Mar-94 & & & & Apr-94 & May-95 & 14 \\
\hline Peak at & May-95 & Jun-95 & Nov-97 & 30 & & & \\
\hline Trough at & Nov-97 & & & & Dec-97 & Feb-98 & 3 \\
\hline Peak at & Feb-98 & Mar-98 & Nov-02 & 57 & & & \\
\hline Trough at & Nov-02 & & & & Dec-02 & Feb-04 & 15 \\
\hline Peak at & Feb-04 & Mar-04 & Oct-08 & 56 & & & \\
\hline Trough at & Oct-08 & & & & Nov-08 & & \\
\hline Average Duration & & & 37 & & & 12 \\
\hline
\end{tabular}


Table 2e - Continuation

\begin{tabular}{|l|c|c|c|c|c|c|c|}
\hline & PSE & Bear & Period & $\begin{array}{c}\text { Duration } \\
\text { (months) }\end{array}$ & Bull & Period & $\begin{array}{c}\text { Duration } \\
\text { (months) }\end{array}$ \\
\hline Trough at & Feb-92 & & & & Mar-92 & Dec-93 & 22 \\
\hline Peak at & Dec-93 & Jan-94 & Jan-95 & 13 & & & \\
\hline Trough at & Jan-95 & & & & Feb-95 & May-95 & 4 \\
\hline Peak at & May-95 & Jun-95 & Aug-97 & 27 & & & \\
\hline Trough at & Aug-97 & & & & Sep-97 & Oct-98 & 14 \\
\hline Peak at & Oct-98 & Nov-98 & Jan-00 & 15 & & & \\
\hline Trough at & Jan-00 & & & & Feb-00 & Aug-00 & 7 \\
\hline Peak at & Aug-00 & Sep-00 & Sep-01 & 13 & & & \\
\hline Trough at & Sep-01 & & & & Oct-01 & Jun-03 & 21 \\
\hline Peak at & Jun-03 & Jul-03 & Nov-03 & 5 & & & \\
\hline Trough at & Nov-03 & & & & Dec-03 & Jun-07 & 43 \\
\hline Peak at & Jun-07 & Jul-07 & Oct-08 & 16 & & & \\
\hline Trough at & Oct-08 & & & & Nov-08 & May-09 & 7 \\
\hline Peak at & May-09 & Jun-09 & & & & & \\
\hline Average Duration & & & 15 & & & 17 \\
\hline
\end{tabular}

\begin{tabular}{|c|c|c|c|c|c|c|c|}
\hline & sSI & Bear & Period & $\begin{array}{l}\text { Duration } \\
\text { (months) }\end{array}$ & Bull & Period & $\begin{array}{l}\text { Duration } \\
\text { (months) }\end{array}$ \\
\hline Trough at & Aug-92 & & & & Sep-92 & Aug-93 & 12 \\
\hline Peak at & Aug-93 & Sep-93 & Nov-94 & 15 & & & \\
\hline Trough at & Nov-94 & & & & Dec-94 & May-96 & 18 \\
\hline Peak at & May-96 & Jun-96 & Aug-97 & 15 & & & \\
\hline Trough at & Aug-97 & & & & Sep-97 & Oct-98 & 14 \\
\hline Peak at & Oct-98 & Nov-98 & Mar-01 & 29 & & & \\
\hline Trough at & Mar-01 & & & & Apr-01 & Nov-01 & 8 \\
\hline Peak at & Nov-01 & Dec-01 & May-06 & 54 & & & \\
\hline Trough at & May-06 & & & & Jun-06 & Sep-07 & 16 \\
\hline Peak at & Sep-07 & Oct-07 & Sep-08 & 12 & & & \\
\hline Trough at & Sep-08 & & & & Oct-08 & May-09 & 8 \\
\hline Peak at & May-09 & Jun-09 & & & & & \\
\hline \multicolumn{2}{|c|}{ Average Duration } & & & 25 & & & 13 \\
\hline
\end{tabular}


Table 2e - Continuation

\begin{tabular}{|l|c|c|c|c|c|c|c|}
\hline & THSE & Bear & Period & $\begin{array}{c}\text { Duration } \\
\text { (months) }\end{array}$ & Bull & Period & $\begin{array}{c}\text { Duration } \\
\text { (months) }\end{array}$ \\
\hline Trough at & Oct-91 & & & & Nov-91 & May-95 & 43 \\
\hline Peak at & May-95 & Jun-95 & Aug-97 & 27 & & & \\
\hline Trough at & Aug-97 & & & & Sep-97 & Oct-98 & 14 \\
\hline Peak at & Oct-98 & Nov-98 & Feb-00 & 16 & & & \\
\hline Trough at & Feb-00 & & & & Mar-00 & Jan-01 & 11 \\
\hline Peak at & Jan-01 & Feb-01 & Sep-01 & 8 & & & \\
\hline Trough at & Sep-01 & & & & Oct-01 & Jan-06 & 52 \\
\hline Peak at & Jan-06 & Feb-06 & Dec-06 & 11 & & & \\
\hline Trough at & Dec-06 & & & & Jan-07 & Jul-07 & 7 \\
\hline Peak at & Jul-07 & Aug-07 & Oct-08 & 15 & & & \\
\hline Trough at & Oct-08 & & & & Nov-08 & Apr-09 & 6 \\
\hline Peak at & Apr-09 & May-09 & now & & & & \\
\hline Average Duration & & & 11 & & & 22 \\
\hline
\end{tabular}

Source: Author's calculations

\section{Characteristics of stock market cycles}

Table 3 shows the average cycle length for stock markets between January 1991 until June 2010. The average duration of contraction in stock markets for the PRC and India was generally shorter than stock markets in ASEAN-5 and the developed economies. This implies that the emerging markets experienced rapid recovery from stock market downturn and frequent fluctuation between two phases in stock market. On the average, stock market in emerging economies will stay at each phase for about 15 months only.

The study finds that for developed countries, on the average, expansion episodes for the U.S. were the longest (27 months), while Japan had the shortest expansion periods amongst all the countries in this study (10 months). The mean durations of bear market for the two developed economies' stock markets fluctuated between 18 months (the U.S.) and 28 months (Japan). These two developed economies displayed two different scenarios in their stock market characteristic, where the U.S. stock market was able to sustain the prosperity in stock market while Japanese stock market was fragile during expansion regimes and sluggish in recovery.

The mean duration for the bull periods for ASEAN-5 stock markets ranges from 12 to 22 months, while for bear phases the mean duration ranges from 11 months to 37 months. On the average, duration of upturns in stock markets for Indonesia, Malaysia and Singapore was 12 months, while for the Philippines and Thailand was 19.5 months. One should note that, Malaysian's stock market spent the longest time in bear phases among ASEAN-5 stock markets (with 37 months which equivalent to 3 
years), while Thailand displayed the lowest duration spent in bear phases (11 months). The rest of ASEAN-5 stock markets spent around 14 to 25 months in their bear periods. The results show that ASEAN-5 stock markets experienced shorter bull phases than bear phases. This implies that ASEAN-5 stock markets were vulnerable to external shock during the bull period and had slow recovery once entering the bear period. In summary, the results show asymmetry of bear duration in ASEAN-5 stock markets.

Table 3

Duration of Expansion and Contraction for Stock Market Cycle (January 1991 - June 2010)

\begin{tabular}{|l|c|c|}
\hline & Bear Duration (months) & Bull Duration (months) \\
\hline SHCI & 18 & 14 \\
\hline BSE & 12 & 16 \\
\hline DJII & 18 & 27 \\
\hline NIK & 28 & 10 \\
\hline JSE & 17 & 12 \\
\hline KLCI & 37 & 12 \\
\hline PSE & 15 & 17 \\
\hline SSI & 25 & 13 \\
\hline THSE & 11 & 22 \\
\hline
\end{tabular}

\section{Concordance of Stock Market Cycles}

This section presents the synchronicity of stock market cycles with two types of indices, namely CI and RCI. CI is an index, which indicates the degree of synchronisation of the cycles as presented in Table 4 . The CI tells the portion of time concurrently spent at the same regime by two countries. RCI is shown in Figure 1, which displays the concordance behaviour of the cycle in a dynamic manner. Thus, the CI reveals the degree of financial integration amongst the countries in this study while RCI reveals the degree of financial integration in a dynamic approach.

\section{Concordance Index (Cl)}

Table 4 reports the matrices of concordance indices amongst countries based on the $\mathrm{B} \& \mathrm{~B}$ procedure throughout the full sample period. The stock markets concordance of ASEAN-5 with the PRC is close to 0.5 except for the Philippines (0.44) and Thailand (0.38). This implies that within the entire period taken into consideration in this study, around $50 \%$ of the time, the stock market cycles of Indonesia, Malaysia and Singapore coincide with PRC stock markets cycle. However, the PRC stock market cycle was less synchronised to the Philippines and Thailand's stock market cycles movement. 
India's stock market cycle shows high degree of concordance with the Philippines and Thailand stock market cycles with $61 \%$ of time aligned with the Indian stock market cyclical movement. The stock markets for Singapore and Indonesia coincide marginally with India's stock market movement with concordance indices at 0.54 and 0.52 , respectively. The stock market concordance index between India and Malaysia was the lowest amongst ASEAN-5, with only $47 \%$ of co-movement time.

The ASEAN-5 stock markets observed an average concordance index of 0.55 with the U.S. stock market. This implies around 55\% of the ASEAN-5 stock markets movement were aligned with the movement in the U.S. stock market. The highest index of concordances for stock market was between Japan and Indonesia, which was recorded at 0.71. This indicates that the Japanese and the Indonesian's stock market cyclical movement had $71 \%$ of time rest in a similar phase. Overall, the Japanese stock market exhibited an above average co-movement with each of the ASEAN-5 stock markets namely, KLCI (0.5), PSE (0.61), SSI (0.52) and THSE (0.63).

Table 4

Concordance Indices (January 1991 - June 2010)

\begin{tabular}{|l|c|c|c|c|c|}
\hline & JSE & KLCI & PSE & SSI & THSE \\
\hline SHCI & 0.54 & 0.50 & 0.44 & 0.57 & 0.38 \\
\hline BSE & 0.54 & 0.47 & 0.61 & 0.52 & 0.61 \\
\hline DJII & 0.53 & 0.55 & 0.57 & 0.53 & 0.60 \\
\hline NIK & 0.71 & 0.50 & 0.61 & 0.52 & 0.63 \\
\hline
\end{tabular}

\section{Rolling Concordance Index ( $\mathrm{RCl}$ )}

Figure 1 shows graphical comparison for the phases of stock market cycles derived from the B\&B algorithm. The graphs in Figure 1 present RCIs between ASEAN-5 stock markets with individual stock markets in emerging and developed economies.

\section{Model 1: ASEAN-5 Stock Markets with the PRC Stock Market}

The RCIs of ASEAN-5 stock markets with the PRC stock market fluctuated a lot over the period of study. Figure 1a visibly shows that the RCIs can be divided into two periods, pre-2000 and post-2000. During pre-2000 period, the RCIs hover between 0.3 and 0.6, indicating a lack of synchronisation amongst the stock market cycles. The RCI amongst these six stock markets plunged during the Asian financial crisis. This reflects that the PRC stock market did not suffer from Asian-originated financial contagion. The RCIs amongst these countries stayed at a low level of around 0.3 throughout the crisis. However, after year 2000, ASEAN-5 stock markets and the PRC stock market have become increasing concordant especially between the PRC and Indonesia as well as the 
Philippines. The stock market RCIs amongst these six countries reached as high as 0.8 . However, Thailand stock market seemed to be less synchronised with the PRC. Their average RCIs was below 0.5. The stock market RCIs of the PRC with Malaysia started to drop significantly from 0.8 in 2004 to 0.3 in 2007 but showed a sign of increase in 2008. During post-2000s, Malaysia was in the prolonged bear market of 56 months while the PRC was in the transition from end of bear to bull market. As for the RCIs between the PRC and Singapore, there was a sign of decreasing concordance in stock market cyclical movement in the mid of 2006. Nevertheless, the RCIs between the PRC and Singapore remained relatively high and stable at the level above 0.6. All the stock market RCIs between ASEAN-5 and the PRC are above 0.5 in 2010, suggesting the stock market cycles in the region progressively become more synchronised.

Figure 1a

$\mathrm{RCl}$ between Stock Markets in ASEAN-5 and the PRC

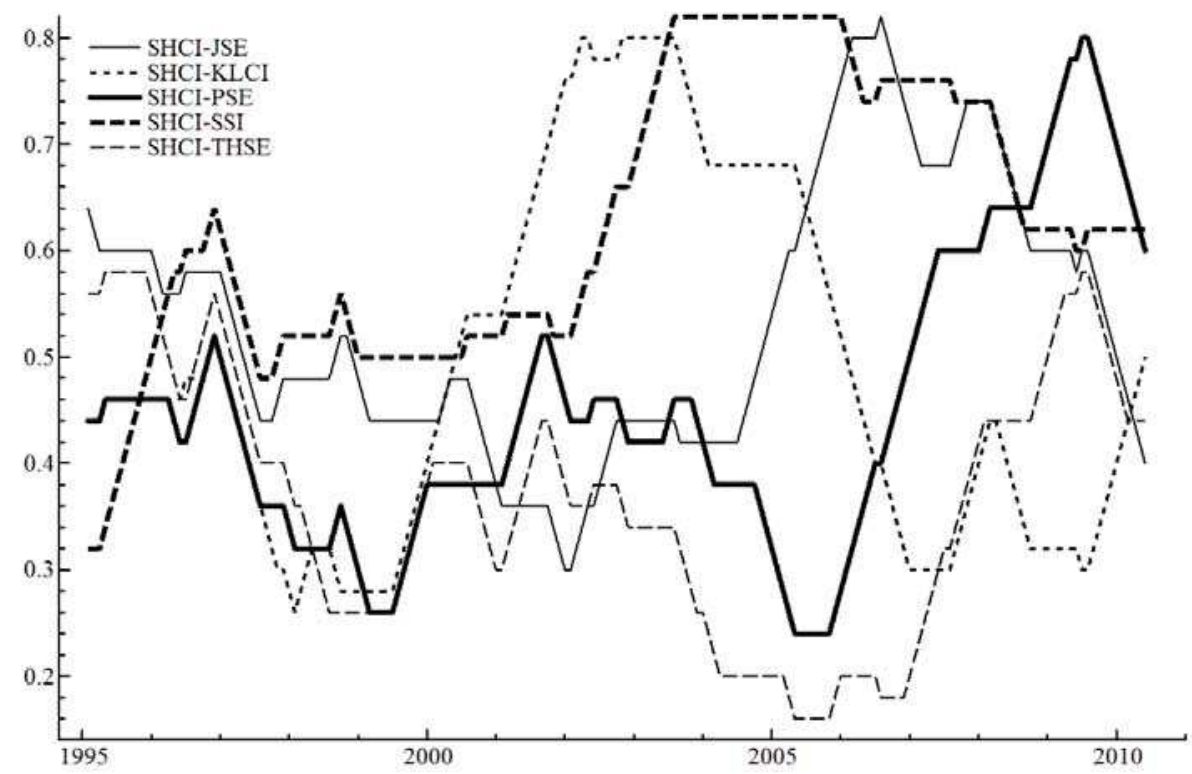

Source: Author's calculations

\section{Model 2: ASEAN-5 Stock Markets with India Stock Market}

As shown in Figure 1b, the RCIs of India's stock market with ASEAN-5 stock markets started to move upwards since 1990s but fluctuated widely downwards after Asian financial crisis in 1997, which fell from 0.8 (September, 1997 in the Philippines) to 0.2 (October, 2001 in Singapore). This indicates that India's stock market moved relatively less dependent from ASEAN-5 stock markets and the crisis did not drag down India's 
stock market. After 2002, ASEAN-5 stock markets showed an increasing trend of RCIs with India's stock market until it hit a high value of 0.9 in 2010 (for Singapore with India). Stock markets in ASEAN-5 had high RCIs with India stock market after 2005. This implies that the two regions reached a high degree of synchronisation after 2005.

Figure $1 b$

RCI between Stock Markets in ASEAN-5 and India

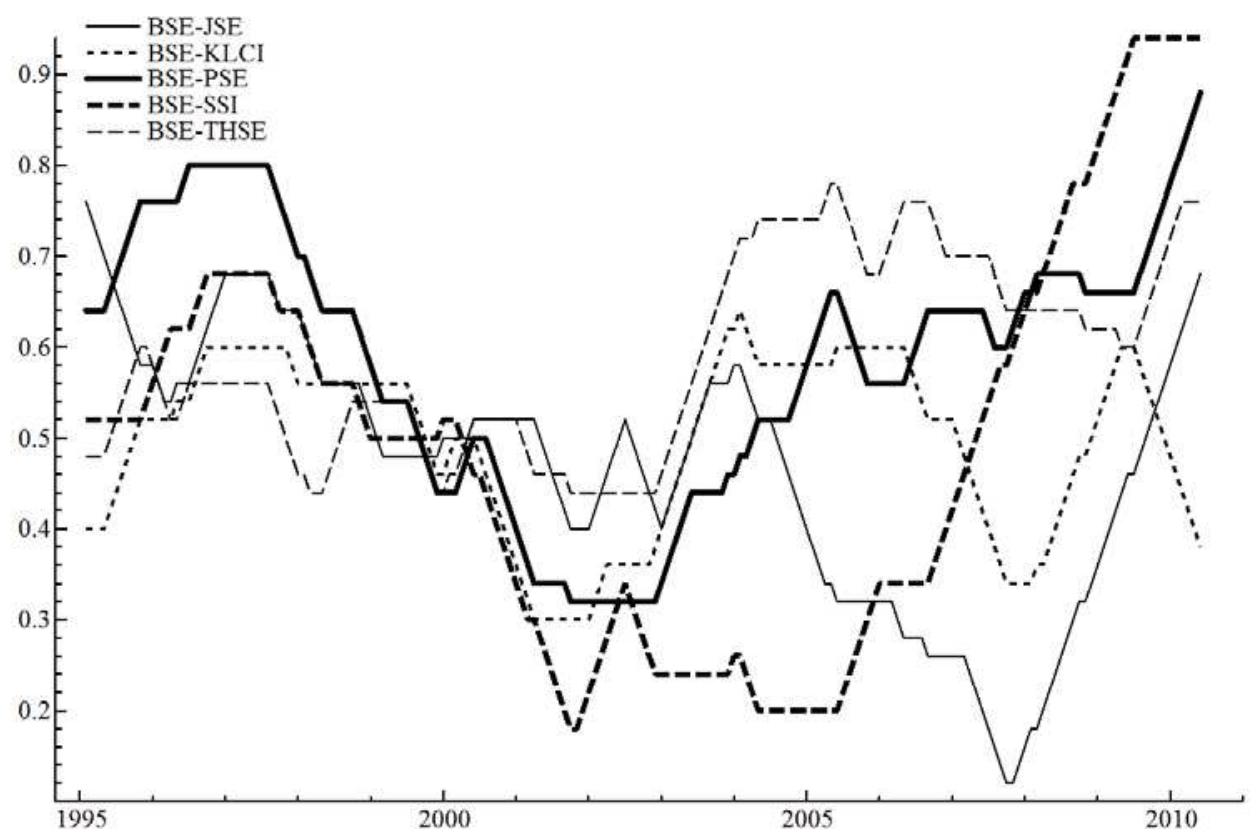

Source: Author's calculations

\section{Model 3: ASEAN-5 Stock Markets with the U.S. Stock Market}

The U.S. and ASEAN-5 show high concordance in their regime changes for stock markets with wide fluctuation over the time span considered for this study. Since 1995, the RCIs amongst these six countries started high with 0.96 (DJII-THSE) and the rest with the average of above 0.5 with decreasing trend except for Indonesia, which experienced an increasing trend. In late 1997, the U.S. stock market cycle was not concordant with the ASEAN-5 stock market during the eruption of Asian financial crisis even though the U.S. stock market was also in their bear period. Hence, this implies that the crisis did not affect the U.S. stock market entering bear period. ASEAN-5 stock markets seemed to be aligned with the U.S.' internet bubble burst in early 2000 and progressed into the stock market downturn of 2002. Singapore and Malaysia were able to diverge from the U.S. stock market movement starting from 2004 with a significant fall of RCIs until to the 
level of 0.1 (Singapore) and 0.38 (Malaysia) while the rest of ASEAN-5 stock markets remained highly concordance with the U.S. The divergence of Singapore and Malaysia's stock market cycle movement from the U.S. as these two markets are well-established is comparable to the other three stock markets in ASEAN-5. However, during the subprime crisis in 2007, ASEAN-5 stock markets started to show rising concordance with the U.S. In summary, ASEAN-5 stock market cycles showed a high degree of synchronisation when crisis happened in the U.S., while crisis originated from ASEAN displayed low synchronisation between these two regions.

Figure 1c

$\mathrm{RCI}$ between Stock Markets in ASEAN-5 and the U.S.

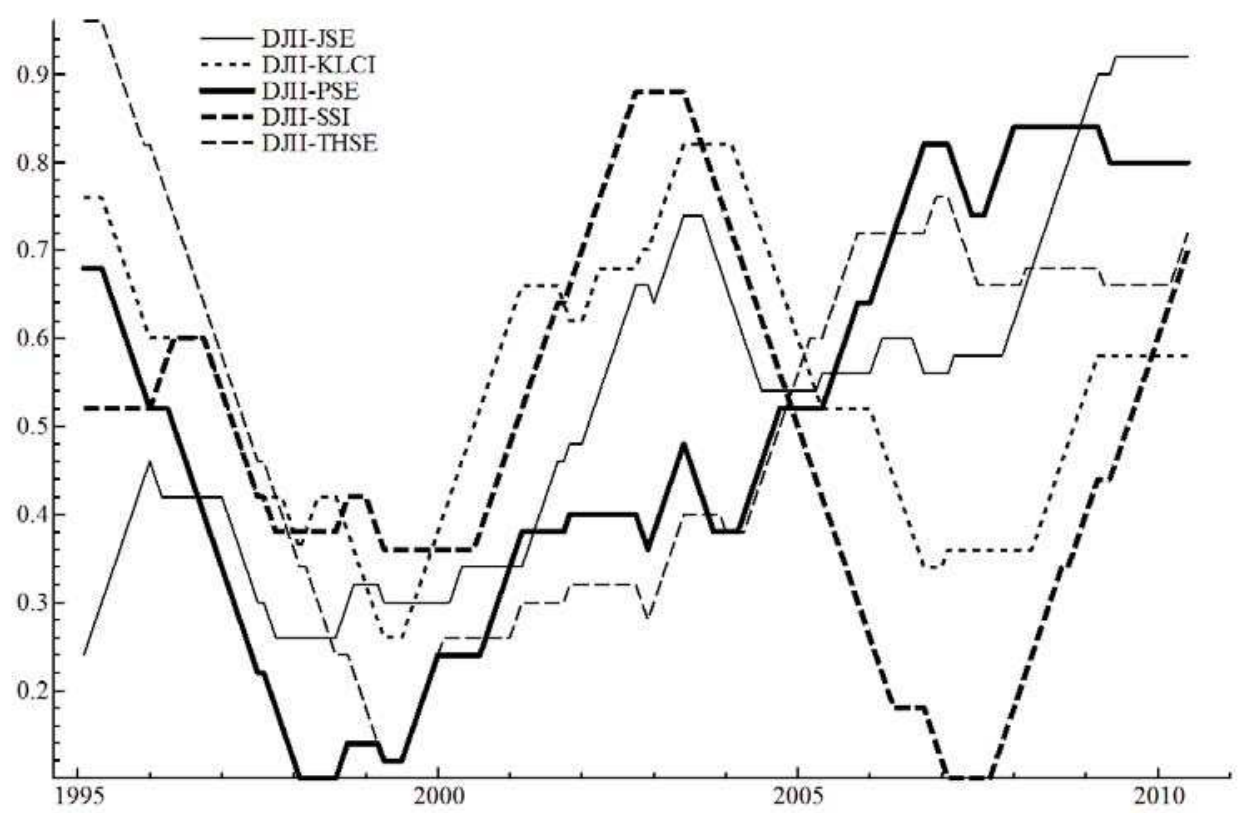

Source: Author's calculations

\section{Model 4: ASEAN-5 Stock Markets with Japan Stock Market}

The RCIs between stock markets in ASEAN-5 region and Japan have consistently ranges between 0.2 (KLCI-NIK) and 0.8 (JSE-NIK) but vary a lot over the period of study. Japanese stock market was insured against the contagion of Asian financial crisis as the RCIs between these two regions exhibit a declining trend after 1997. Throughout that period, Japan was at the bull market flooded with hot money, while ASEAN-5 suffered a bear market. In the early 2000s, ASEAN-5 stock markets moved at an opposite direction from the stock market in Japan with the exception of Thailand. Thailand was also suffering from a bear market as Thailand economy has not recovered from 
the aftermath effect of 1997 Asian financial crisis. Thailand only recovered from the impact of the crisis in 2004. The stock market RCIs of Japan with ASEAN-5 (except for the Philippines) displayed significant concordance after 2006, around the dates of implementation of new monetary policy in Japan.

Figure 1d

$\mathrm{RCl}$ between Stock Markets in ASEAN-5 and Japan

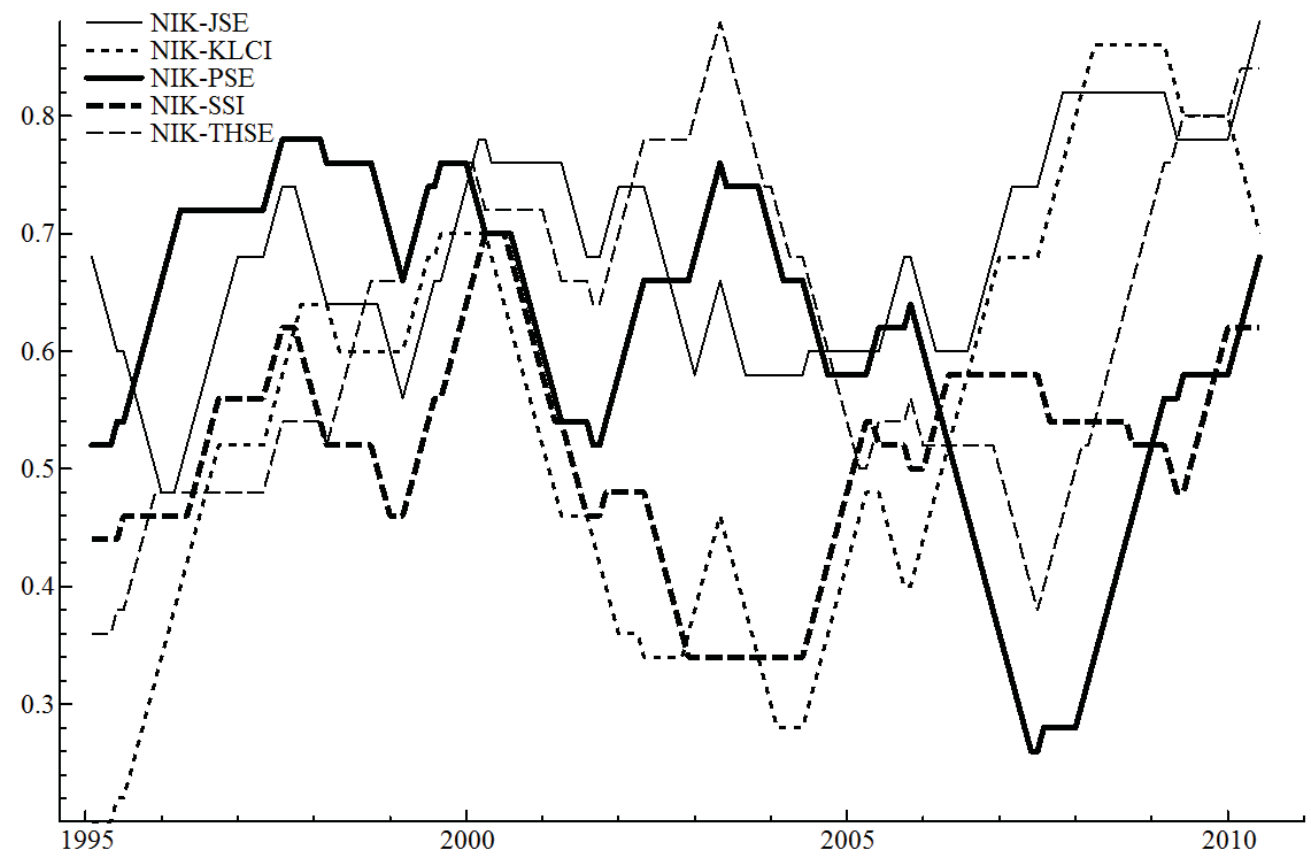

Source: Author's calculations

\section{Discussion and Conclusion}

The results of the CI between stock markets show that stock market cycle in Indonesia was more synchronised with Japan stock market cycle (71\%) while only marginally aligned with stock market cycle in the PRC, India and the U.S. Stock market cycles between Malaysia with the PRC, India, the U.S. and Japan only shared approximately half $(50 \%)$ of the time in similar cyclical phase. Both PSE and THSE stock market cycles indicated relatively low CI with SHCI stock market cycle (below 45\%) but higher concordance with BSE, DJII and NIK cyclical movement (above 56\%). The CI between SSI and SHCI was slightly higher (57\%) as compared to the other three markets which were below the average of $55 \%$ concordance.

The RCI for the cyclical movement was used to assess the trend of economic integration in a time-varying manner. The results indicate that RCI between ASEAN-5 and SHCI 
fluctuated in a narrow band at low concordance level during pre-2004 but vital changes were observed after 2004 where the RCI between them fluctuated in broader band at higher degree of concordance. The RCI of SHCI with KLCI increased tremendously after 2009. The RCI between ASEAN-5 and BSE started with high-synchronised movement but slowdown during the stock market meltdown and subprime crisis. After the subprime crisis, the RCI between BSE and ASEAN-5 rose dramatically except with KLCI. The results for ASEAN-5 and DJII non-parametric time varying concordance were not a surprise. Their RCI was the highest amongst the pairs of countries in this study and both regions' stock markets only diverged during the Asian financial crisis and subprime crisis. Some of the ASEAN-5's RCI with DJII even dropped to zero during these crises which imply that the crises was not transmitted to the particular countries. There was a significant upward moving trend between the RCI of ASEAN-5 and NIK since 1990s. Their linkages stabilised during the Asian financial crisis but slowdown since 2000s after the implementation of quantitative easing strategy in Japan. Their RCI only picked up again after 2005, which coincided with the abolishment of quantitative easing strategy.

Overall, the CI results indicate higher financial interdependence of ASEAN-5 with the U.S. and Japan. The financial integration between ASEAN-5 and emerging economies is only marginal. The stock markets RCIs amongst ASEAN-5 with the emerging and developed economies depict an upward moving trend that indicates the rising financial integration amongst these nations. The level of financial integration amongst ASEAN-5 stock markets with the PRC has gradually increased. However, it is still relatively lower compared to the financial integration with India, the U.S. and Japan. Hence, the financial portfolio diversification of ASEAN-5 to the PRC is recommended especially if the financial crisis originates from the ASEAN region.

\section{References}

Arouri, M. H., Nguyen, D. K. (2009), "Time-varying Characteristics of Cross-market Linkages with Empirical Application to Gulf Stock Markets". Managerial Finance, Vol. 36, No. 1, pp. 57-70.

Arouri, M. H., Jawadi, F., Nguyen, D. K. (2008), "International Stock Return Linkages: Evidence from Latin American Markets". European Journal of Economics, Finance and Administrative Sciences, Vol. 11.

Avouyi-Dovi, S., Matheron, J. (2005), "Interactions between Business Cycles, Stock Market Cycles and Interest Rates: the Stylised Facts". Banque de France Working Paper No.121.

Azad, A. S. M. (2009). "Efficiency, Cointegration and Contagion in Equity Markets: Evidence from China, Japan and South Korea". Asian Economic Journal Vol. 23, No. 1, pp. 93-118.

Baele, L., Ferrando, A., Hördahl, P., Krylova, E., Monnet, C. (2004), "Measuring Financial Integration in the Euro Area". European Central Bank Occasional Paper No.14.

Beirne, J., Caporale, G.M., Schulze-Ghattas, M., and Spagnolo, N. (2009), "Volatility Spillovers and Contagion from Mature to Emerging Stock Markets". European Central Bank Working Paper Series 1113. Available from: http://ssrn.com/abstract_id=1502468 [Accessed 10 June 2010]

Bekaert, G., Harvey, C. R. (1997), "Emerging Equity Market Volatility". Journal of Financial Economics, Vol. 43, pp. 29-77. 
Bry, G., Boschan, C. (1971), Cyclical Analysis of Time Series: Selected Procedures and Computer Programs. New York: National Bureau of Economic Research.

China Economic Review (2011), “Qualified Domestic Institutional Investor 2011”. Available from: http:// www.chinaeconomicreview.com [Accessed on 19th September 2011]

Click, R. W., Plummer, M. G. (2005), "Bond Market Development and Integration in ASEAN". International Journal of Finance \& Economics, Vol. 10, No. 2, pp. 133-142.

Edwards, S., Biscarri, J. G., Perez de Gracia, F. (2003), "Stock Market Cycles, Financial Liberalisation and Volatility”. Journal of International Money and Finance, Vol. 22, No. 7, pp. 925-955.

World Bank (2011), Financial Sector. Washington: World Bank. Available from: http://data.worldbank. org/topic/financial-sector [Accessed on $8^{\text {th }}$ June 2011]

Girardin, E., Liu, Z. (2007), "The Financial Integration of China: New Evidence on Temporally Aggregated Data for the A-Share Market". China Economic Review, Vol. 18, pp. 354-371.

Guillaumin, C. (2009), "Financial Integration in East Asia: Evidence from Panel Unit Root and Panel Cointegration Tests". Journal of Asian Economics, Vol. 20, No. 3, pp. 314-326.

Huang, B. N., Yang, C. W., Hu, J. (2000), "Causality and Cointegration of Stock Markets among the United States, Japan and the South China Growth Triangle". International Review of Financial Analysis, Vol. 9, No. 3, pp. 281-297.

Huyghebaert, N., Wang, L. (2010). "The Co-movement of Stock Markets in East Asia Did the 1997-1998 Asian Financial Crisis Really Strengthen Stock Market integration?" China Economic Review, Vol. 21, pp. 98-112.

International Monetary Fund (various issues), International Financial Statistics (monthly), Washington: International Monetary Fund.

Karim, B. A., Majid, M. S. A. (2009), "International Linkages among Stock Markets of Malaysia and its Major Trading Partners". Journal of Asia-Pacific Business, Vol. 10, No. 4, pp. 326-351.

Lean, H. H., Ghosh, B. N. (2010), "Economic Integration in Asia: Quo Vadis Malaysia?" International Economic Journal, Vol. 24, No. 2, pp. 237-248.

Lim, L. K. (2009), "Convergence and Interdependence between ASEAN-5 Stock Markets". Mathematics and Computers in Simulation, Vol. 79, pp. 2957-2966.

Majid, M. S. A., Meera, A. K. M., Omar, M. A., Aziz, H. A. (2009), "Dynamic Linkages among ASEAN-5 Emerging Stock Markets". International Journal of Emerging Markets, Vol. 4, No. 2, pp. 164-184.

Meric, G., Leal, R. P. C., Ratner, M., Meric, I. (2001), "Co-movements of U.S. and Latin American Equity Markets before and after the 1987 Crash". International Review of Financial Analysis, Vol.10, pp. 219-235.

Pagan, A. R., Harding, D. (2002), "Dissecting the Cycle: a Methodological Investigation". Journal of Monetary Economics, Vol. 49, No. 2, pp. 365-381.

Pagan, A. R., Harding, D. (2005), "A Suggested Framework for Classifying the Modes of Cycle Research". Journal of Applied Econometrics, Vol. 20, No. 2, pp. 151-159.

Pagan, A. R., Sossounov, K. A. (2003), "A Simple Framework for Analysing Bull and Bear Markets". Journal of Applied Econometrics, Vol. 18, No. 1, pp. 23-46.

Phylaktis, K., Ravazzolo, F. (2002), "Measuring Financial and Economic Integration with Equity Prices in Emerging Markets". Journal of International Money and Finance, Vol. 21, No. 6, pp. 879-903.

Rana, P. B. (2007), "Economic Integration and Synchronisation of Business Cycles in East Asia". Journal of Asian Economics, Vol.18, pp. 711-725.

Yu, I.-W., Fung, K.-P., Tam, C.-S. (2010), "Assessing Financial Market Integration in Asia-equity Markets”. Journal of Banking \& Finance, Vol. 34, No. 12, pp. 2874-2885. 


\section{Appendix 1:}

Procedure for Programmed Determination of Turning Points for Stock Market Return Index

1. Determination of initial turning points in raw data.

a. Determination of initial turning points in raw data by choosing local peaks (troughs) as occurring when they are the highest (lowest) values in a window eight months on either side of the date.

b. Enforcement of alternation of turns by selecting highest of multiple peaks (or lowest of multiple troughs).

2. Censoring operations (ensure alternation after each).

a. Elimination of turns within 8 months of beginning and end of series.

b. Elimination of peaks (or troughs) at both ends of series which are lower or higher).

c. Elimination of cycles whose duration is less than 16 months.

d. Elimination of phases whose duration is less than 4 months (unless fall/rise exceeds $20 \%$ ).

3. Statement of final turning points

Source: Pagan and Sossounov [2003, pp. 44-45]. 